УДК 37

\title{
ТЕХНОЛОГИЯ МЕНТОРСКОГО СОПРОВОЖДЕНИЯ В СИСТЕМЕ ОБРАЗОВАНИЯ
}

\author{
Володина Маргарита Павловна \\ старший преподаватель \\ кафедры психологии и педагогики \\ Международная полицейская академия ВПА
}

\begin{abstract}
Аннотация. В данной статье рассматривается проблема модернизации и совершенствования системы наставничества в современном образовательном учреждении. Наставничество переходит на новую ступень развития менторство. Особое внимание уделяется личности наставника, ментора, который не только передает конкретные знания и навыки, а делится жизненным опытом, поддерживает, направляет молодого специалиста, помогает ему успешно пройти адаптацию и ведет к достижению профессиональных целей. В статье кратко изложены основные принципы и методы менторского сопровождения.
\end{abstract}

Ключевые слова: наставничество, менторство, ментор, модель GROW, дорожная карта, успешная адаптация, молодой специалист.

\section{Актуальность наставничества и менторского сопровождения}

Любой человек, начинающий свой путь в профессии, испытывает затруднения из-за отсутствия опыта. Как правило, начинающий учитель имеет хорошую теоретическую подготовку, но слабо представляет себе повседневную педагогическую практику. Сейчас молодым педагогам намного сложнее. XXI век требует небывалой скорости развития. Новые ценности информационного общества заставляют задуматься над вопросом, каким должно быть современное образование. Наибольшего внимания к себе в этих условиях требует сама личность человека, стоящая в центре всех педагогических концепций последнего времени. Ее качественные изменения, ответственность и готовность к самореализации, способность социализироваться и адаптироваться к быстроменяющемуся миру - все это требует особой заботы и обусловливает специфику современного образования. Это означает, что происходит все большая актуализация 


\section{МОДЕРНИЗАЦИЯ СОВРЕМЕННОГО ОБРАЗОВАНИЯ: АНАЛИЗ ОПЬТА И ТЕНДЕНЦИЙ}

необходимости перемен в системе образования. Требуется действительная и действенная модернизация образования: модернизация приоритетов, ценностей, отношений, взаимодействий Профессиональное становление молодого педагога - сложный процесс. От того, как пройдет этот процесс, зависит, станет ли молодой учитель профессионалом, останется ли он в сфере образования или решит уйти в другую сферу деятельности. Многие молодые педагоги уходят из образовательных организаций, проработав годдва, так как не смогли справиться с трудностями педагогической деятельности, а помочь им было не кому.

Возникающие у молодого педагога трудности связаны, во-первых, со слабой методической подготовкой, отсутствием опыта организации своей педагогической деятельности, сложностями владения приемами и методами обучения; во-вторых, со сложностью адаптации в новом коллективе.

Одной из проблем в деятельности любого образовательного учреждения является включение молодого учителя в сложную полифункциональную педагогическую деятельность, которая является целостным, длительным и непрерывным процессом, ориентированным на формирование личностных качеств, профессиональных способностей, знаний, умений и навыков, адекватных как его личностным потребностям, так и квалификационным требованиям. Именно в первые годы работы активно формируются те качества, которые впоследствии определят степень его мастерства. Задача наставника - проявляя тактичность, человеческую и профессиональную мудрость, оказать поддержку молодому специалисту в приобретении нового практического опыта. Работа с молодыми специалистами сегодня является приоритетным направлением в работе икольл.

С целью более эффективного вхождения молодых специалистов в профессию разработана система сопровождения, которая учитывает индивидуальные особенности молодого педагога и способствует формированию у него мотивации к самосовершенствованию, саморазвитию, самореализации. Такой системой является наставничество или менторство форма профессионального становления и воспитания молодых педагогов под наблюдением наставника, где наставник, ментор высококвалифицированный педагогический работник, проводящий в индивидуальном порядке работу с молодыми специалистами по их адаптации к педагогической деятельности и последующему профессиональному 
развитию, обладающий высокими профессиональными и нравственными качествами, практическими знаниями и опытом.

Хороший наставник должен быть не просто успешным педагогом. Он должен обладать характером и желанием помогать развиваться другим людям. Это требует готовности размышлять и делиться собственным опытом, в том числе и негативным. Хороший наставник искренне заинтересован в том, чтобы помочь кому-то еще без какой-либо «официальной» награды. Он делает это потому, что искренне желает, чтобы кто-то другой также добился успеха и был счастлив в профессии, в нем есть желание вкладывать энергию и силу в развитие своего подопечного. Вот тогда наставник и выходит на новый уровень - становится МЕНТОРОМ.

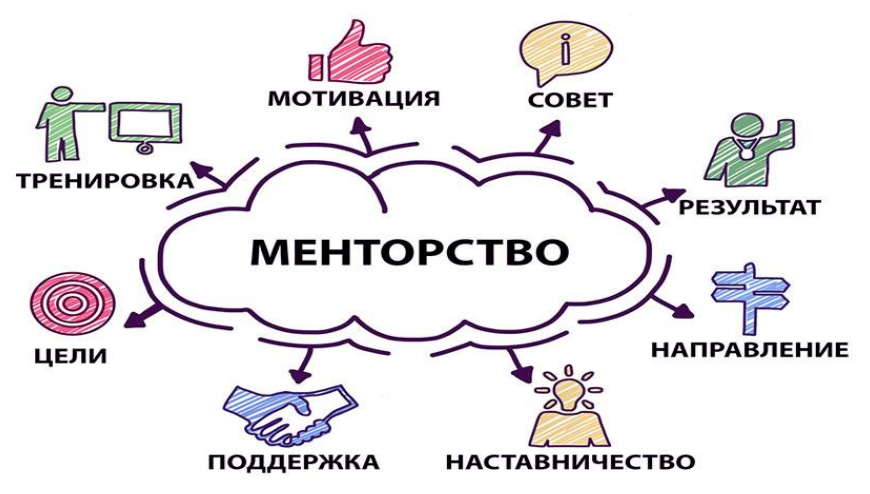

Рис. 1

\section{Цели и задачи наставничества}

Целью наставничества является оказание помощи молодым учителям в их профессиональном становлении, а также формирование в центре образования кадрового ядра.

Задачи:

- всесторонне развивать имеющиеся у молодого педагога знания в области педагогики и предметной специализации, методики преподавания, способности самостоятельно и качественно выполнять возложенные на них задачи по занимаемой должности;

- оказывать помощь молодому педагогическому работнику в освоении профессии и овладении в полном объеме должностными обязанностями за счет ознакомления с современными методами и приемами педагогического труда, передачи наставником личного опыта; 


\section{МОДЕРНИЗАЦИЯ СОВРЕМЕННОГО ОБРАЗОВАНИЯ: АНАЛИЗ ОПЬТА И ТЕНДЕНЦИЙ}

- вовлекать молодого педагогического работника в образовательный трудовой процесс и общественную жизнь центра образования с учетом его индивидуальных склонностей, закрепление его в профессии;

- создавать условия для адаптации молодого педагогического работника в коллективе, помогать ему осваивать корпоративную культуру, принимать традиции трудового коллектива и правила поведения в центре образования;

- создавать условия для максимального раскрытия индивидуальных возможностей молодого учителя;

- оказывать своевременную поддержку педагогических инициатив с организацией исследовательской деятельности молодого педагога;

- формировать нравственные принципы, чувство долга и ответственности, уважение к профессии и добросовестное отношение к профессиональной деятельности;

- создавать условия для повышения профессионального мастерства и квалификации молодых педагогических работников, для становления и развития их профессиональных качеств и компетенций;

- обеспечивать постоянное совершенствование форм и методов наставничества;

- мотивировать молодого педагогического работника к установлению стабильных, длительных трудовых отношений в коллективе, снижать текучесть кадров;

- способствовать усвоению лучшего опыта и традиций коллектива образовательной организации молодым педагогическим работником;

- способствовать созданию в коллективе благоприятного социальнопсихологического климата и творческого настроя на дальнейшую деятельность;

- ускорять процесс профессионального становления и развития, творческого самоопределения учителя.

\section{Принципы наставничества}

В основе любой деятельности всегда лежит руководящая идея, основное правило, основное требование к деятельности и поведению, вытекающее из установленных наукой закономерностей. Их выполнение гарантирует нужный эффект при решении поставленных задач.

При организации деятельности в рамках наставничества необходимо соблюдать общие начальные положения, отображающие основные требования к содержанию, формам, методам и способам организации данного процесса. 


\section{МОДЕРНИЗАЦИЯ СОВРЕМЕННОГО ОБРАЗОВАНИЯ: АНАЛИЗ ОПЫТА И ТЕНДЕНЦИЙ}

Принципы, лежащие в основе наставнической деятельности, не представляют собой готовые и универсальные правила взаимодействия с наставляемым, они строятся на основе личностных особенностей тандема наставникнаставляемый и особенностей организации образовательного процесса и корпоративной культуры в любом центре образования.

$>$ Принцип системности и последовательности.

$>$ Принцип программно-целевого подхода.

$>$ Принцип добровольности.

$>$ Принцип конструктивного профессионального взаимодействия.

$>$ Принцип ответственности.

\section{Модели взаимодействия в контексте наставничества}

Наставничество должно стимулировать потребности молодого педагога в самосовершенствовании, способствовать его профессиональной и личностной самореализации. Эффективность наставничества, на наш взгляд, зависит от того, какие модели взаимодействия с наставляемым берет за основу наставник. В практике наставнической деятельности существуют следующие модели взаимодействия с подопечным молодым педагогом, позволяющие быстро и качественно решать задачи профессионального становления молодого специалиста, включать его в проектирование своего развития, оказывать ему помощь в самоорганизации, самоанализе своего развития, повышать его профессиональную компетентность:

Таблица 1

\begin{tabular}{|l|l|}
\hline \multicolumn{1}{|c|}{ Модель наставничества } & \multicolumn{1}{|c|}{ Описание системы работы } \\
\hline $\begin{array}{l}\text { Традиционное наставничество на } \\
\text { постоянной продолжительной } \\
\text { основе }\end{array}$ & Наставник работает с наставляемым по системе один - один \\
\hline Ситуативное наставничество & $\begin{array}{l}\text { Предоставление наставником необходимой помощи всякий } \\
\text { раз, когда подопечный нуждается в указаниях и } \\
\text { рекомендациях }\end{array}$ \\
\hline Целеполагающее наставничество & $\begin{array}{l}\text { Наставник и наставляемый встречаются по заранее } \\
\text { установленному графику для постановки конкретных } \\
\text { долгосрочных целей, ориентированных на определенные } \\
\text { педагогические результаты }\end{array}$ \\
\hline $\begin{array}{l}\text { Наставничество в режиме } \\
\text { разработки и реализации } \\
\text { образовательных проектов }\end{array}$ & $\begin{array}{l}\text { Совместная деятельность наставника и наставляемого по } \\
\text { разработке и реализации образовательного проекта }\end{array}$ \\
\hline
\end{tabular}


Продолжение таблицы 1

\begin{tabular}{|l|l|}
\hline Флеш - наставничество & Стандартная сессия флэш-наставничества: одноразовая \\
& встреча, лично или с помощью телекоммуникационных \\
& технологий, которая может продолжаться от нескольких \\
& минут до нескольких часов \\
& Скоростное наставничество: однократные \\
& непродолжительные встречи (до 30 минут), в ходе которых \\
& наставником и наставляемым уточняются общие цели, \\
& обозначаются возникающие проблемы, обсуждаются пути их \\
& решения \\
\hline Виртуальное наставничество & Советы и рекомендации наставником предоставляются в \\
& режиме онлайн \\
\hline
\end{tabular}

Модель GROW

В центре менторского сопровождения целесообразно поставить модель GROW. Это простой, но мощный инструмент для структурирования деятельности ментора, который помогает следовать вектору менторского сопровождения.

\section{МОДЕЛЬ GROW}

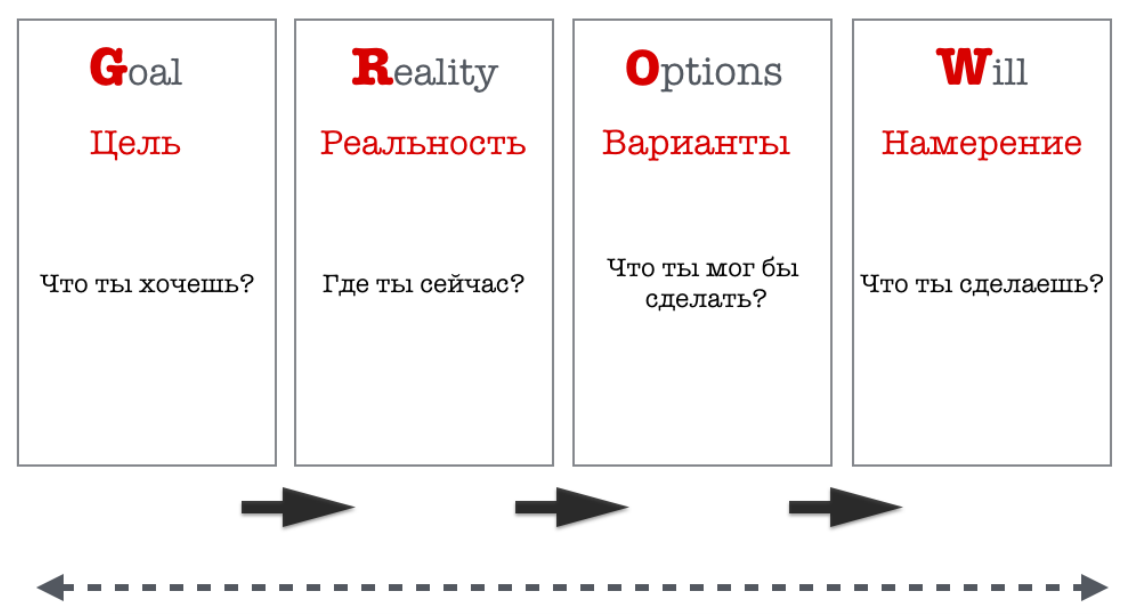

Рис. 2

Рассмотрим эту модель детально:

\section{G (Goal - цель)}

Намечаем цеель, которую будем достигать вместе с наставляемым. Ключевые вопросы:

\section{- Чего мы хотим?}


- Какой результат будет лучшим?

- Что ты получишь из того, чего у тебя нет сейчас?

- Как ты поймешь, что цель достигнута?

- Соответствует ли цель общему плану профессионального развития?

\section{R (Reality - реальность)}

Оцениваем и описываем существующую реальность.

Ключевые вопросы:

- Что происходит в данный момент?

- Какими ресурсами мы сейчас обладаем?

- Какие барьеры есть на пути к желаемому?

- Что больше всего тревожит?

\section{O (Options - опции, обстоятельства)}

Проводим «мозговой штурм», придумываем максимум возможных вариантов и альтернатив, обсуждаем пути преодоления.

Ключевые вопросы:

- Что мы можем изменить?

- Как мы это сделаем?

- Какие методы работы выберем?

- Что надо перестать делать, чтобы достичь цели?

- Какие инструменты есть в нашей профессиональной копилке?

W (will - воля, действие)

Создаем конкретный план действий.

Ключевые вопросы:

- Каким будет твой первый шаг?

- Как ты сможешь поддерживать на хорошем уровне свою мотивацию?

- Какая поддержка тебе нужна?

- Когда нужно будет оценить прогресс?

Формы и методы взаимодействия наставника и наставляемого отличаются большим разнообразием. Это связано с тем, что в работе наставника, в зависимости от вида наставничества и особенностей конкретной ситуации, могут быть использованы методы, заимствованные из педагогики, социальной работы, профконсультирования, психологии. В практике наставнической деятельности эффективно используют также следующие методы:

\footnotetext{
$>$ наблюдение;

$>$ беседа;
} 
$>$ знакомство с документацией;

$>$ изучение передового педагогического опыта;

$>$ обмен опытом;

$>$ самообразование;

$>$ анкетирование;

$>$ моделирование;

$>$ проектная деятельность;

$>$ рефлексия;

$>$ комплексная оценка.

\section{Дорожная карта профессионального становления молодого учителя}

Важным аспектом вхождения молодого педагога в профессию является его профессиональный рост. Одной из технологий развития профессиональной компетентности педагогов служит индивидуальный образовательный маршрут.

На основе личных образовательных потребностей молодого учителя, потребностей образовательной организации разрабатывается Дорожная карта профессионального становления молодого специалиста.

При проектировании индивидуального образовательного маршрута молодому педагогу оказывается консультативная помощь и предоставляется информация о возможностях методической работы в образовательном учреждении для развития профессиональной компетентности и возможностях обучения и развития профессиональной компетентности вне школы (курсовая подготовка в системе повышения квалификации, городские педагогические сообщества, виртуальные предметные педагогические сообщества, семинары известных ученых и практиков, открытые мероприятия, форумы, фестивали, дистанционное обучение, электронные ресурсы и т. п.).

Характерными чертами индивидуального образовательного маршрута является то, что в нем полнее отражаются личные образовательные потребности педагога, большее место отводится самообразованию и развитию профессиональной компетентности в контексте профессиональной деятельности, т. е. педагог предстает сформировавшимся субъектом развития своей профессиональной компетентности. В Дорожной карте можно найти:

- сведения об образовании наставника и молодого специалиста;

- информацию об этапах профессионального становления (адаптационный, проектировочный, контрольно-оценочный); 
- карту индивидуального образовательного маршрута педагога по развитию профессиональной компетентности;

- направление и содержание деятельности;

- средства по выявлению и устранению профессиональных дефицитов;

- план профессионального развития;

- деятельность педагога в профессиональном сообществе;

- способы совершенствования профессионально значимых личностных качеств и черт характера молодого специалиста.

Менторское сопровождение позволяет молодому специалисту почувствовать уверенность в своих силах, поддержку мудрого наставника профессиональную и психологическую. Работа наставника сложная и кропотливая. Необходимо уделять время и силы своему подопечному. Подводя итоги, можно утверждать, что менторское сопровождение в профессиональной деятельности является важной составляющей модернизации образовательной системы.

(C) М.П. Володина, 2021 